\title{
American Studies in Scandinavia - Special issue on the Arctic
}

In 2019 US President Donald Trump proposed that the US buy Greenland from Denmark. The latter nation rejected this suggestion and many news outlets poked fun of the idea. Trump's proposition, however, reveals a number of problematic implications about the Arctic as a place and concept. Since at least the 1860s, the US has attempted to buy the island several times and this most recent attempt reveals the persistence of a certain kind of imperialist arrogance on both the Danish and US-American side of the question. It signals that Greenland (and the whole Arctic by implication) is a place to be purchased, a colonially controlled space without voice or agency.

In this special issue, we want to explore the multiple ways in which the Arctic and the United States intersect discursively, culturally, ideologically, legally, politically, and economically. Some of the questions we are interested in answering are: Why is the United States interested in the Arctic? What role has the United States and the Scandinavian countries historically played in the region? How has the Arctic been portrayed historically, culturally, and literarily? What kinds of decolonial and indigenizing processes are happening in the Arctic in the 21 st century as well as historically? What role does climate change play on Arctic communities and economies? Etc.

We invite papers on topics related to the Arctic from anyone working in Arctic Studies, American Studies, history, literary studies, cultural studies, ethnography, economics and law, to name a few. Possible topics include but are not limited to the following: 
- What and where is the Arctic?

- Arctic vulnerabilities

- Affect and the Arctic

- The Arctic in American literature

- The Arctic in popular culture

- The Arctic in visual art

- Indigenous histories of the Arctic

- Indigenous art

- Indigenous literature

- Colonialism and exploitation

- De-, post-, and anti-colonialism

- Indigenization and self-determination

- Early settlers and Arctic histories

- Contested spaces and landscapes

- The Arctic as center and periphery

- Cultural change in the arctic

- Arctic representations of the so-called West

- Arctic cultural and literary interventions and inventions

- The Arctic in the Anthropocene

- Climate change

- Climate activism

- China in the Arctic

- Literature in/about Greenland

- Literature in/about Alaska

- Literature in/about Northern Canada

- The Arctic as American Dream

- Gender constructs in the Arctic

- The LGBTQIA+ Arctic

- Arctic family dynamics

- Arctic masculinities

If you have questions about this CFP, please contact Clara Juncker or Marianne Kongerslev. If you want to propose a topic not listed here, we welcome you to do so.

Please send proposals for papers (max 300 words) to Clara Juncker (juncker@sdu.dk) and Marianne Kongerslev (kongerslev@hum.aau.dk) by December 1, 2021. Final papers must be submitted by May 1, 2022. 